\title{
Acompliment econòmic i financer en empreses no familiars i empreses familiars amb CEO familiar i extern
}

\author{
Roxana Daniela Nerghes \\ Graduada en Administració i Direcció d'Empreses per la Universitat de Lleida \\ *Correu de contacte: rn4@alumnes.un
}

Rebut 31 de maig de 2020 ; Revisat 12 de novembre de 2020; Acceptat 20 de novembre de 2020

\begin{abstract}
Resum
L'objectiu d'aquest treball és analitzar les empreses no familiars i les empreses familiars amb CEO familiar i CEO extern, des d'un punt de vista econòmic i financer, amb la finalitat de poder determinar si les empreses familiars amb CEO extern presenten un comportament similar al d'una empresa no familiar. Per a poder realitzar l'estudi, d'una banda des d'un punt de vista teòric i sobre la base de la literatura s'han explicat les característiques pròpies l'empresa familiar i la influència que el tipus de CEO exerceix sobre la gestió d'aquesta. D'altra banda, a partir d'una mostra d'empreses seleccionada a través de la base de dades SABI durant el període comprès entre l'any 2012 i l'any 2016, s'ha dut a terme una anàlisi financera emprant una sèrie de ràtios. Els resultats obtinguts corroboren que les empreses familiars amb CEO extern s'aproximen més a un estil de gestió propi d'una empresa no familiar, ja que tendeixen a assumir majors riscos, presenten majors nivells d'endeutament i major orientació a beneficis.
\end{abstract}

Classificació JEL: G32, L25, M10

Paraules Clau: Empresa familiar, Empresa no familiar, CEO, Ràtios

\section{Introducció}

L'empresa familiar és el tipus d'empresa que predomina tant a nivell nacional com internacional. És tanta la seva importància, que actualment aquest tipus d'organitzacions conformen la columna vertebral de l'economia de molts països i és per aquest motiu que les empreses familiars s'han convertit en l'objecte d'estudi de nombrosos autors.

A l'hora d'estudiar aquestes companyies, molts autors han constatat que un factor rellevant a tenir en compte era la naturalesa del $\mathrm{CEO}$, ja que aquest genera diferències en quant a la gestió de l'empresa i per tant en els resultats obtinguts.

Llavors, si l'empresa familiar amb CEO extern difereix de l'empresa familiar amb CEO familiar es pot afirmar que la manera de gestionar l'empresa dels CEO externs 
s'assembla més al d'una empresa no familiar? És per aquesta qüestió que s'ha decidit realitzar aquest treball de recerca, que té com a objectiu general identificar les diferències $\mathrm{i}$ similituds que pot haver-hi entre les empreses no familiars $\mathrm{i}$ les empreses familiars amb CEO extern.

Per a això s'ha decidit estructurar el treball en dues parts:

- En la primera part es farà una revisió de la bibliografia i s'exposaran des d'un punt de vista teòric aspectes com el concepte d'empresa familiar, les característiques pròpies d'aquesta mena d'organització, la importància del CEO en les empreses i la influència que la naturalesa del CEO exerceix en la gestió de les empreses familiars.

- En el segon apartat es durà a terme una anàlisi quantitativa. S'analitzaran un conjunt de ràtios financers $\mathrm{i}$ econòmics amb la finalitat de poder contrastar els resultats obtinguts amb els aspectes teòrics.

\section{Empresa familiar vs. Empresa no familiar}

\subsection{Presència de l'Empresa Familiar a Espanya}

Les empreses d'origen familiar suposen una part molt important del teixit empresarial i, per tant, la seva importància des d'un punt de vista quantitatiu és significativa en l'economia dels diferents països i regions, independentment del seu nivell de desenvolupament.

Són molts els estudis realitzats a Europa, els Estats Units i Amèrica Llatina que posen de manifest que aquesta figura empresarial arriba a suposar entre el $70 \%$ i el $90 \%$ de total d'empreses d'un país (Amat, 2004).

L'any 2016 el Instituto de la Empresa Familiar, organització empresarial independent sense ànim de lucre que agrupa un centenar d'empreses líders en els seus sectors d'activitat, en col-laboració amb la seva xarxa de càtedres, va publicar l'informe L'empresa Familiar a Espanya (Instituto de la Empresa Familiar, 2015), que té com a principal objectiu l'estimació del pes que les empreses de tipus familiar tenen en l'economia espanyola.

A continuació, sobre la base del treball L'empresa Familiar a Espanya (Instituto de la Empresa Familiar, 2015) es procedirà a explicar de forma resumida la presència de les empreses familiars tant a nivell nacional, com per Comunitats Autònomes (CC.AA.) i la seva incidència en les principals variables macroeconòmiques, com per exemple l'ocupació i el PIB, entre altres.

Segons els resultats obtinguts per l'Institut de l'Empresa Familiar s'estima que 1,1 milions d'empreses són familiars a Espanya, aquesta xifra representa el 88,8\% sobre el total d'empreses analitzades.

En quant a la seva distribució per Comunitats Autònomes (CC.AA.) els valors se situen entre el 84,4\% (País Basc) i el 94,3\% (Castilla-La Mancha). No obstant això, aquest estudi també posa de manifest que a l'hora de calcular el percentatge d'empreses familiars segons la grandària les xifres varien, i la seva presència disminueix a mesura que augmenta la grandària de l'empresa. 
Pel que fa la distribució per sectors, l'estudi mostra una alta presència de l'empresa familiar en tots els sectors econòmics, encara que cal destacar que la seva presència predomina en el sector primari, secundari, el sector de la construcció, comerç i hostaleria.

Referent al pes que les empreses familiars tenen en els principals agregats macroeconòmics, l'Institut de l'Empresa Familiar estima, d'una banda, que les empreses d'origen familiar representaven el $57,1 \%$ del valor afegit brut generat per les SA i SL existents a Espanya al 2013, excloent els autònoms. Comunitats Autònomes com Extremadura i Galícia són on més destaquen, ja que aquest índex arribava a superar el $80 \%$.

D'altra banda, en quant a l'ocupació, els resultats obtinguts per l'IEF indiquen que l'empresa familiar espanyola té un pes important en la generació d'ocupació a nivell nacional. Els resultats obtinguts per Espanya mostren que aquest tipus d'empreses creen el $66,7 \%$ de l'ocupació total, és a dir, aproximadament 6,6 milions de llocs de treball.

\subsection{Definició d'Empresa familiar}

A causa de la falta d'acord sobre què s'entén per empresa familiar actualment existeix una àmplia varietat de definicions que s'han utilitzat en la literatura al llarg del temps per a tractar de descriure aquest tipus d'organitzacions.

En una primera aproximació Shanker i Astrachan (1996) citat en Corona (2005) proposen una classificació tridimensional de les definicions:

- en sentit ampli, l'empresa familiar es caracteritza pel control efectiu des de la direcció estratègica, amb l'objectiu que la família no perdi la seva posició dominant com a propietària encara que participi poc en la gestió directa.

- en sentit intermedi, s'identifica amb una empresa dirigida pel fundador o els seus hereus exercint un control legal de les accions amb vot $i$ on la família té certa participació en la gestió.

- en sentit restrictiu, es planteja una empresa amb gran participació de múltiples generacions familiars, involucrades en la direcció i en la propietat on diversos familiars tenen importants responsabilitats de gestió.

Els tres aspectes contemplats en la majoria de definicions i als quals fan referència la gran majoria dels autors a l'hora de descriure les empreses familiars són: la propietat, la direcció i la continuïtat en mans de la família.

Tenint en compte aspectes com la propietat i el control Davis i Harveston (1998) defineixen les empreses familiars com aquelles que es diferencien de les no familiars per trobar-se la seva propietat controlada per membres de la família, el que els permet al mateix temps exercir una gran influència en els aspectes específics d'aquesta. En aquest sentit, Barnes i Hershon (1994) defineixen empresa familiar com aquella en la qual la propietat de control està atribuïda a algun membre o membres d'una única família.

Des del punt de vista de la direcció, Filbeck i Lee (2000) assenyalen que una empresa familiar és aquella en la qual les decisions més importants són preses pel fundador o per algun descendent d'aquest. 
Finalment, en quant a la continuïtat, Ward (1988) defineix aquest tipus d'empreses com aquella que serà transferida a la següent generació de la família perquè la dirigeixi o la controli.

La definició oficial del terme d'Empresa Familiar aprovada el 2008 per les dues principals institucions internacionals representants de l'Empresa Familiar: a Brussel·les, pel Grup Europeu d'Empresa Familiar (GEEF), que actualment es coneix com European Family Business (EFB), i a Milà, pel Board del Family Business Network (FBN) estableix el següent:

«Una companyia sense importar la seva grandària és considerada familiar si compleix les següents condicions:

- La majoria dels vots són propietat de la persona o persones de la família que va fundar o van fundar la companyia; o, són propietat de la persona que té o ha adquirit el capital social de l'empresa; o són propietat de les seves esposes, pares, fill(s) o hereus directes del fill(s).

- La majoria dels vots pot ser directa o indirecta.

- Almenys un representant de la família o parent participa en la gestió o govern de la companyia.

- A les companyies cotitzades se'ls aplica la definició d'Empresa Familiar si la persona que va fundar o va adquirir la companyia (el seu capital social), o els seus familiars o descendents posseeixen el $25 \%$ dels drets de vot als quals dóna dret el capital social.»

Un dels problemes que presenta aquesta definició és que no té en compte aspectes de tipus qualitatiu, com per exemple, el propòsit de mantenir l'empresa de generació en generació, la qual cosa dota a la empresa d'un caràcter veritablement familiar.

Finalment, és imprescindible destacar que encara que moltes vegades les empreses familiars s'han equiparat amb les petites i mitjanes empreses (PIME), aquestes no són el mateix. A pesar que generalment solen ser de petita dimensió, les empreses familiars també tenen un paper destacat dins de les principals i més grans companyies d'un país (Amat, 2004).

\subsection{Característiques de l'empresa familiar}

\section{- Finançament}

L'interès dels fundadors i successors de l'empresa familiar per mantenir el control i la gestió de l'empresa en mans de la família, juntament amb la preferència per evitar la incertesa en les seves inversions financeres són els principals objectius d'aquesta mena d'organització.

Tal i com explica Corona (2005) en el Manual de l'Empresa Familiar, aquests dos objectius condicionen les decisions de finançament, les polítiques de dividends, la inversió, i per tant la dimensió i el creixement de l'empresa.

Les empreses familiars, segons apunta Corona (2005) davant la necessitat de finançament, opten primer per l'autofinançament, és a dir, per la reinversió dels 
beneficis, deixant en segon pla les ampliacions de capital i l'endeutament. En quant a les ampliacions de capital, l'autor assenyala que aquesta alternativa presenta certes dificultats ja que, d'una banda, les primeres generacions ja tenen vinculat el seu patrimoni a l'empresa i difícilment podran aportar nous recursos financers i, d'altra banda, realitzar ampliacions de capital permetent l'entrada de nous socis no familiars xocaria amb l'interès dels seus fundadors per mantenir el control de l'empresa.

Per tant, realitzar ampliacions de capital no resulta una opció viable per a l'empresa i això provoca que les empreses familiars utilitzin la reinversió dels beneficis com a font principal de finançament. No obstant això, la capacitat de retenció de beneficis es pot veure afectada a mesura que noves generacions s'incorporen en l'empresa ja que augmenten la seva demanda de repartiment de dividends reduint així la capacitat de retenció de beneficis de l'empresa (Corona, 2005).

Respecte al finançament aliè, diversos autors com Agrawal i Nagarajan (1990), Lyagoubi (2006) i Mishra i Mcconaughy (1999) assenyalen que les empreses familiars són reticents a acudir a l'endeutament, degut al risc financer que això implica i que pot provocar una pèrdua del control de l'empresa. No obstant això, si l'autofinançament és insuficient per a fer front a les seves necessitats, les empreses familiars preferiran l'endeutament per a cobrir aquest dèficit, utilitzant les ampliacions de capital com a últim recurs (Mahérault, 2000).

En definitiva, les empreses familiars com a primera opció preferiran l'autofinançament, en segon lloc l'endeutament bancari quan els beneficis retinguts són insuficients, i per últim les ampliacions de capital.

No obstant això, les decisions de finançament que adoptin les empreses familiars condicionen la seva capacitat d'inversió i creixement (Corona, 2005). És a dir, optar per l'autofinançament per a no perdre el control de l'empresa pot afectar a la seva estratègia de creixement, ja que per a créixer necessitarà finançament aliè.

\section{- Grandària}

L'Institut de l'Empresa Familiar, en el seu estudi "Factores de competitivitat y anàlisis financero de la Empresa Familiar" presentat l'any 2018, analitza una sèrie de variables que caracteritzen a l'empresa familiar en funció de la seva grandària i l'impacte que cadascuna d'elles exerceix en el creixement de l'empresa familiar.

La distribució per dimensió de les empreses enquestades per l'Institut de l'Empresa Familiar es pot observar en la següent taula: 
Taula 1. Distribució de les empreses familiars per grandària

\begin{tabular}{|lc|}
\hline Nombre de treballadors & $\%$ \\
\hline Fins a 9 (micro) & 24,1 \\
10 a 49 (petita) & 65,7 \\
50 a 249 (mitjana) & 8,7 \\
Més de 250 (gran) & 1,5 \\
Total & 100 \\
\hline
\end{tabular}

Font: Instituto de la empresa familiar (2018)

Una de les variables analitzades en aquest treball és la naturalesa del CEO. Analitzant la grandària de l'empresa segons si el CEO és membre de la família propietària o és extern, una de les conclusions a les quals es va arribar és que la presència d'un familiar ocupant el càrrec de directiu disminueix a mesura que augmenta de grandària l'empresa (Taula 2).

Taula 2. Percentatge de CEO familiars per grandària d'empresa

\begin{tabular}{|lcc|}
\hline & CEO familiar & CEO no familiar \\
\hline Micro & $93.0 \%$ & $7.0 \%$ \\
Petita & $90,3 \%$ & $9,7 \%$ \\
Mitjana & $84,1 \%$ & $15,9 \%$ \\
Gran & $55,6 \%$ & $44,4 \%$ \\
\hline
\end{tabular}

Font: Instituto de la empresa familiar (2018)

S'aprecia que el 93\% dels directius de les microempreses són de naturalesa familiar. Aquest percentatge es veu reduït a mesura que les empreses augmenten la seva grandària, encara que les variacions entre les petites i mitjanes empreses no són significatives. No obstant això, quan ens referim el grup de les grans empreses, s'observa que la presència de CEOs familiars es redueix pràcticament a la meitat. Per tant, aquests resultats donen suport a la idea que les empreses familiars no haurien de descartar la possibilitat de nomenar a un CEO no familiar.

També s'arriba a la conclusió que el nivell de formació del CEO augmenta a mesura que s'incrementa la grandària de l'empresa (Taula 3). Això es deu, probablement al fet que una major dimensió de l'empresa necessita una gestió més professionalitzada que moltes vegades és difícil trobar dins de la mateixa família. 


\begin{tabular}{|lcccc|}
\hline \multicolumn{5}{c}{ Taula 3. Formació del CEO per grandària empresarial } \\
\hline & $\begin{array}{r}\text { Estudis no } \\
\text { universitaris }\end{array}$ & $\begin{array}{c}\text { Estudis universitaris } \\
\text { de perfil econòmic }\end{array}$ & $\begin{array}{c}\text { Altres estudis } \\
\text { universitaris i de } \\
\text { postgrau. }\end{array}$ & NS/NC \\
\hline Micro & $49 \%$ & $28,8 \%$ & $21,2 \%$ & $1 \%$ \\
Petita & $52,5 \%$ & $28,5 \%$ & $18,8 \%$ & $0,02 \%$ \\
Mitjana & $22,7 \%$ & $48,9 \%$ & $28,4 \%$ & $0 \%$ \\
\hline Gran & $0 \%$ & $44,4 \%$ & $55,6 \%$ & $0 \%$ \\
\hline
\end{tabular}

Font: Instituto de la empresa familiar (2018)

\section{- Nivell de formació}

El nivell de formació en les empreses familiars ha estat un dels principals desafiaments als quals ha hagut de fer front aquest tipus d'organitzacions al llarg del temps.

Les conclusions a les quals arriba l'estudi realitzat per l'Institut de l'Empresa Familiar (2018) s'enumeren a continuació:

- el grau de formació es veu reduït a mesura que augmenta l'antiguitat del CEO.

- quan la propietat està en mans de la primera i segona generació és més probable que el nivell d'estudis del CEO sigui menor.

- les empreses gestionades per CEO universitaris posseeixen normalment òrgans de govern com a consell d'administració, equip directiu o junta d'accionistes.

- el nivell d'internacionalització és menor quan els directius manquen de formació universitària. Per contra, si posseeixen estudis del perfil econòmic el nivell d'internacionalització augmenta.

- el nivell de formació del CEO també influeix en els objectius estratègics que es persegueixen en l'empresa, de manera que quan al CEO li manca formació universitària, aquest s'enfocarà principalment a mantenir viva l'empresa.

- en canvi, si el CEO posseeix estudis universitaris és estadísticament més freqüent que els objectius estratègics perseguits siguin augmentar la dimensió de l'empresa, així com el seu valor en el mercat.

\section{CEO familiar o CEO extern}

\subsection{Importància del CEO en les empreses}

CEO són les sigles de Chief Executive Officer i fan referència al conseller delegat o director executiu d'una empresa. És a dir, el màxim responsable de la gestió i direcció d'una companyia.

Castaldi (1986) i Etebari et al. (1987) assenyalen que el lloc del director executiu és el més important dins d'una empresa i enumeren una sèrie de responsabilitats que aquests han d'assumir i un conjunt d'activitats que han de dur a terme, destacant entre aquestes les següents: 
- planificació a llarg termini: els CEO estableixen els objectius a llarg termini de les empreses i també els mètodes a través dels quals es duran a terme aquests objectius, és a dir, que estableixen el que vol aconseguir l'empresa i de quina manera ho ha d'aconseguir.

- triar als treballadors en àrees no operacionals: el CEO és la figura encarregada de seleccionar als professionals per sota d'ell, que ocupin llocs importants i als quals se'ls assignaran responsabilitats de les quals dependrà l'èxit o fracàs de l'estratègia que es pretén dur a terme en l'empresa.

- exercir de portaveu de l'empresa: una de les responsabilitats del CEO és donar la cara davant els grups d'interès periòdicament per a valorar els esdeveniments passats i determinar els passos a seguir en el futur

- determinar l'estructura organitzativa: el CEO estableix quantes persones formaran part de cada unitat dins de l'organització, quins seran els seus objectius i quines activitats hauran de dur a terme.

\subsection{Gestió segons si el CEO forma part de la família o és extern}

Per a la realització d'aquest apartat s'ha pres com a referència l'estudi "Influencia del CEO en la empresa familiar cotitzada” escrit per Sánchez et al. (2019).

Aquest treball analitza les diferències que es poden presentar dins de les empreses familiars segons la mena de CEO que les dirigeix. És a dir, si forma part de la família o és un professional extern.

Els autors, per a l'elaboració d'aquest estudi, com a mostra, van seleccionar 48 empreses familiars espanyoles, de les quals 26 tenien un CEO extern, i les 22 restants tenien un CEO membre de la família. En quant a les dades financeres emprades per a la realització d'aquest estudi, aquestes es van extreure de la base de dades SABI.

Una vegada seleccionada la mostra, els autors van dur a terme dos tipus d'anàlisis. D'una banda, es van analitzar les variables relatives a l'estructura financera de l'empresa, polítiques de creixement i de distribució de dividends. D'altra banda, van estimar un model de regressió lineal múltiple, per a determinar si la procedència del CEO exerceix una influència sobre la rendibilitat econòmica (ROA).

Els resultats obtinguts d'aquest estudi s'exposen a continuació de manera resumida:

- En relació a la rendibilitat econòmica, els resultats mostren que les empreses familiars amb un CEO extern tendeixen a obtenir major rendibilitat econòmica en termes mitjans, pel fet que aquest tipus de directius posseeixen millors habilitats de gestió, a més d'una major orientació a beneficis.

- En relació a l'estructura financera, els resultats posen de manifest que les empreses familiars amb CEO extern presenten majors nivells d'endeutament, mentre que les empreses familiars amb CEO familiar mostren preferència per l'autofinançament, a causa d'una major aversió al risc i la prioritat per conservar el control de l'empresa. L'indicador de liquiditat mostra que les empreses amb CEO familiar opten per mantenir majors nivells de liquiditat respecte a les empreses amb CEO extern, justificant-se de nou aquests resultats per la major aversió al risc per part dels directius familiars. 
- Respecte al creixement, els resultats obtinguts indiquen que les empreses familiars amb CEO extern experimenten majors creixements en els seus nivells d'actiu, mentre que quan el CEO forma part de la família succeeix tot el contrari.

- Finalment, en quant a la distribució dels resultats, aquest estudi posa de manifest que els CEO externs tendeixen a distribuir major proporció de beneficis en relació al benefici net obtingut, mentre que els CEO familiars opten per reinvertir els beneficis amb el propòsit de finançar el creixement de l'empresa.

Aquest estudi, també posa de manifest una sèrie de teories formulades per diversos autors, en les quals s'assenyalen les diferències entre els CEO que formen part de la família i els CEO externs en les empreses familiars.

Una d'aquestes teories és la teoria de l'agència, desenvolupada per Jensen i Meckling (1976). Aquesta teoria implica la delegació de decisions per part dels propietaris (principal) en mans del CEO (agent). Si tant el principal com l'agent busquen maximitzar el seu propi benefici, pot ser que el CEO prengui certes decisions que no estiguin totalment alineades amb els objectius dels propietaris, de manera que apareixerien els costos d'agència, a causa de motivacions diferents entre agent $\mathrm{i}$ principal, asimetria de la informació i predisposició a assumir diferents nivells de risc.

Altres treballs com Jensen i Murphy (1990) i Devers et al. (2007) consideren les possibles actuacions per a intentar mitigar els conflictes d'agència $i$ els seus costos, a través d'un sistema retributiu que alineés els interessos del CEO extern amb els de l'empresa.

Finkelstein i Hambrick (2009) assenyalen que la naturalesa del CEO pot implicar diferents habilitats de gestió a més dels diferents tipus de problemes d'agència (Jensen i Meckling, 1976). De manera que triar un CEO extern o familiar, dependrà de les característiques de cada empresa i de les habilitats de gestió requerides per cadascuna d'elles. En aquest sentit, Lin i Hu (2007) assenyalen que quan l'empresa requereix d'elevades habilitats gerencials, el rendiment de l'empresa millorarà si el CEO és extern, pel fet que trobar professionals qualificats en el mercat laboral resulta més senzill que trobar-los dins de la mateixa família.

Duréndez i García (2005) apunten que en les empreses familiars, ocasionalment, existeix la voluntat que els membres de la família ocupin els càrrecs de gestió, sense importar si disposen de les qualitats necessàries per a poder fer-ho.

Un altre dels treballs citats és el de Burkart et al. (2003). Aquest treball explica que majors exigències en habilitats directives pot comportar una separació de la propietat $\mathrm{i}$ de l'administració, per mitjà de la contractació d'un CEO extern. No obstant això, el grau de control que exerceix la família sobre les actuacions del CEO extern pot dificultar les tasques dels directius, ja que qualsevol decisió presa per aquests amb la intenció de millorar els resultats de l'empresa pot xocar amb el control exercit per part de la família (Burkart et al., 1997).

Tot el conjunt de resultats i teories exposades anteriorment, sobre la influència que exerceix el tipus de CEO dins de l'empresa familiar, posen de manifest que existeixen diferències significatives en quant a la gestió dins de les empreses familiars en funció de la naturalesa del CEO que les dirigeix. 
Per tant, es podria arribar a pensar que en les empreses familiars, quan són dirigides per directius no familiars, el seu comportament tendeix a aproximar-se més al d'una empresa no familiar. Això es podria justificar per la falta de vinculació des d'una perspectiva natural amb la família, el mateix que ocorre en les empreses no familiars.

\section{Mostra}

La selecció de les empreses de la mostra analitzada en aquest estudi es va dur a terme mitjançant la base de dades SABI (Sistema d'Anàlisi de Balanços Ibèrics), que constitueix la principal base de dades econòmiques i financeres d'empreses espanyoles.

A l'hora de seleccionar la mostra, una de les principals qüestions a la qual ens enfrontem, és la relativa a l'adopció d'una definició per a l'empresa familiar. En aquest estudi s'ha optat per la definició proposada per el Instituto de la Empresa Familiar (2015). Aquesta definició, es basa en els percentatges de capital en mans de la família propietària, no obstant això, té en compte que no és adequat aplicar els mateixos percentatges per a totes les empreses, ja que, en empreses amb una propietat més dispersa, no és necessari un percentatge de propietat tan elevat per exercir el control sobre la companyia. Sobre la base d'aquesta consideració, una empresa adquireix la consideració d'empresa familiar en els següents casos:

- Estructura de propietat dispersa (cap accionista posseeix més del 50\% del capital). L'empresa serà familiar si una persona o família posseeix més d'un 5\% individual o un $20 \%$ en el seu conjunt i a més l'accionista persona física és membre del Consell d'Administració o són accionistes amb més del 20\% del capital i directiu. En cas contrari l'empresa serà classificada com no familiar.

- Estructura de propietat concentrada (algun accionista posseeix més del 50\% del capital). L'empresa serà familiar quan l'accionista familiar controli la propietat amb un percentatge elevat $(50,01 \%)$, o bé en la qual existeixin accionistes-directors amb una participació superior al 50,01\%. Sent no familiars les empreses que no compleixin aquest criteri.

De l'aplicació d'aquests criteris, es van distingir un total de 94.585 empreses familiars i 24.358 empreses no familiars. Per a aquest estudi, d'aquesta mostra inicial es va seleccionar una mostra aleatòria més petita de 750 empreses no familiars. En quant a les empreses familiars incloses en aquest estudi, aquestes corresponen a una mostra de 1.005 empreses familiars espanyoles utilitzades en l'estudi elaborat per el Instituto de la Empresa Familiar (2018). Aquesta mostra es va obtenir de la mostra inicial més àmplia de 94.565 empreses espanyoles que complien amb la definició d'empresa familiar proposada per el Instituto de la Empresa Familiar (2015).

Les dades econòmiques $\mathrm{i}$ financeres de les empreses s'han obtingut a través de la pròpia base de dades SABI. Mentre que la informació relativa a la naturalesa del CEO (si és un membre de la família o extern) en les 1.005 empreses familiars de la mostra es va obtenir a través d'entrevistes telefòniques realitzades al $\mathrm{CEO}$ o màxim responsable de l'empresa mitjançant un qüestionari estructurat.

D'aquesta manera, a partir de la mostra inicial de 1.005 empreses familiars van resultar dues mostres: la primera d'elles composta per 907 empreses familiars amb CEO 
membre de la família i una segona mostra formada per 98 empreses familiars amb CEO extern.

A continuació, una vegada seleccionades les mostres, s'ha procedit a classificar les empreses que les formen segons la grandària d'aquestes. S'ha distingit entre dues dimensions: PIME i grans empreses. Per a dur a terme aquesta classificació s'ha considerat la definició de PIME proposada per la Comissió Europea (2015).

La definició de PIME, segons la Comissió Europea, té en compte els següents criteris:

- ocupen menys de 250 persones; i

- el volum de negoci no excedeix de 50 milions EUR, o bé el balanç general anual no excedeix de 43 milions EUR.

Després d'haver aplicat els criteris esmentats anteriorment, els resultats obtinguts s'han recollit en la següent taula (Taula 4):

Taula 4. Classificació de les empreses no familiars i les empreses familiars amb CEO familiar i CEO extern segons la seva dimensió

\begin{tabular}{|l|cc|cc|cc|}
\hline & \multicolumn{2}{|c|}{ EF CEO familiar } & \multicolumn{2}{|c|}{ EF CEO no familiar } & \multicolumn{2}{c|}{ Empresa no familiar } \\
\hline PIME & 892 & $98,35 \%$ & 91 & $92,86 \%$ & 651 & $86,80 \%$ \\
Gran & 15 & $1,65 \%$ & 7 & $7,14 \%$ & 99 & $13,20 \%$ \\
Total & 907 & $100 \%$ & 98 & $100 \%$ & 750 & $100 \%$ \\
\hline
\end{tabular}

Font: Elaboració pròpia

Els resultats obtinguts posen de manifest que del total de les 907 empreses que formen la mostra d'empreses familiars amb un CEO familiar, les Pimes representen un 98,35\%, deixant tan sols el $1,65 \%$ per a les grans empreses. En el cas de les empreses familiars amb un CEO extern el percentatge d'empreses grans ascendeix a 7,14\% del total de la mostra. Finalment, en quant a la mostra d'empreses no familiars, la xifra d'empreses classificades com a grans empreses se situa en 99, i representen el 13,20\% d'aquesta.

Per tant, tenint en compte els resultats obtinguts de la classificació, es podria arribar a la conclusió que la naturalesa del CEO, és a dir si forma part de la família o és extern, afectarà a la capacitat de creixement de l'empresa, és a dir, que un CEO familiar vetllarà més per la supervivència i els beneficis de l'empresa, els seus dos principals objectius, mentre que el creixement ocuparà una posició secundària (Corona, 2005). En canvi, les empreses no familiars, sense aquestes restriccions al creixement, tendeixen a presentar en termes mitjans una major dimensió.

Si s'analitza l'actiu total mitjà (Taula 5) dels tres grups d'empreses, s'observa que les empreses familiars amb CEO no familiar i les empreses no familiars han experimentat al llarg del període analitzat majors creixements en els seus nivells d'actiu, mentre que les empreses familiars amb CEO familiar presenten uns nivells d'actiu en termes mitjans molt per sota de la mitjana dels altres dos grups d'empreses. 
Tal com s'ha comentat anteriorment, això es deu a la preferència que aquest tipus de directius mostren per mantenir el control de l'empresa, el que limita les possibilitats de creixement de l'empresa.

Taula 5. Actiu total mitjà.

\begin{tabular}{|lccccc|}
\hline Tipus d'empresa & $\mathbf{2 0 1 2}$ & $\mathbf{2 0 1 3}$ & $\mathbf{2 0 1 4}$ & $\mathbf{2 0 1 5}$ & $\mathbf{2 0 1 6}$ \\
\hline EF CEO familiar & $4.433,48$ & $4.372,97$ & $4.527,91$ & $4.838,18$ & $4.869,84$ \\
EF CEO extern & $14.729,19$ & $14.267,63$ & $14.644,99$ & $12.924,53$ & $13.502,23$ \\
Empresa no familiar & $30.432,78$ & $28.500,33$ & $30.619,03$ & $28.989,26$ & $26.947,22$ \\
\hline
\end{tabular}

Figura 1. Evolució de l'actiu total mitjà de les empreses no familiars i empreses familiars amb CEO familiar i CEO extern durant el període 2012-2016

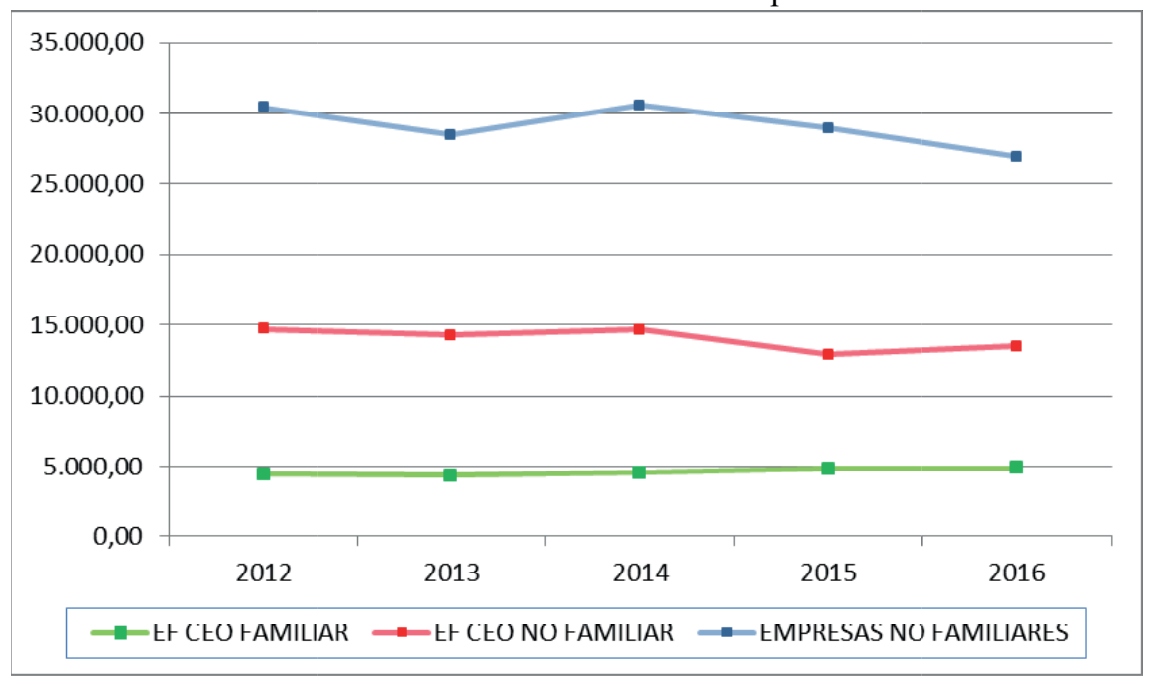

\section{Resultats}

\subsection{Estructura financera}

\subsubsection{Ràtio de garantia}

Ràtio de garantia $=$ Actiu total / Passiu exigible

El ràtio de garantia ens mostra la capacitat total que té l'empresa per a fer front a tots els deutes i obligacions tant a llarg com a curt termini amb el total d'actius dels quals disposa. Per tant, com més gran sigui aquest resultat major serà la garantía i més capacitat tindrà l'empresa per a liquidar els seus deutes. El valor òptim d'aquesta ràtio se situa entre 1,5 i 2,5. Si el resultat fos inferior a 1 pot dir-se que l'empresa no disposa de suficients béns i drets per a assumir les obligacions amb els creditors. A continuació, es mostren els resultats següents: 
Taula 6. Ràtio de garantia.

\begin{tabular}{|lccccc|}
\hline Tipus d'empresa & $\mathbf{2 0 1 2}$ & $\mathbf{2 0 1 3}$ & $\mathbf{2 0 1 4}$ & $\mathbf{2 0 1 5}$ & $\mathbf{2 0 1 6}$ \\
\hline Empresa familiar CEO familiar & 2,82 & 2,84 & 2,77 & 2,95 & 2,99 \\
Empresa familiar CEO extern & 2,83 & 2,89 & 3,34 & 3,85 & 5,11 \\
Empresa no familiar & 2,94 & 3,09 & 3,25 & 3,54 & 3,80 \\
\hline
\end{tabular}

Segons els resultats obtinguts en la taula podem observar que el ràtio de garantia presenta resultats elevats, situats en torn del 2,5 i 3,5 per als tres grups d'empreses, això ens indica un bon nivell de garantia.

Figura 2. Evolució ràtio de garantia empreses no familiars i empreses familiars amb CEO familiar i extern durant el període 2012-2016

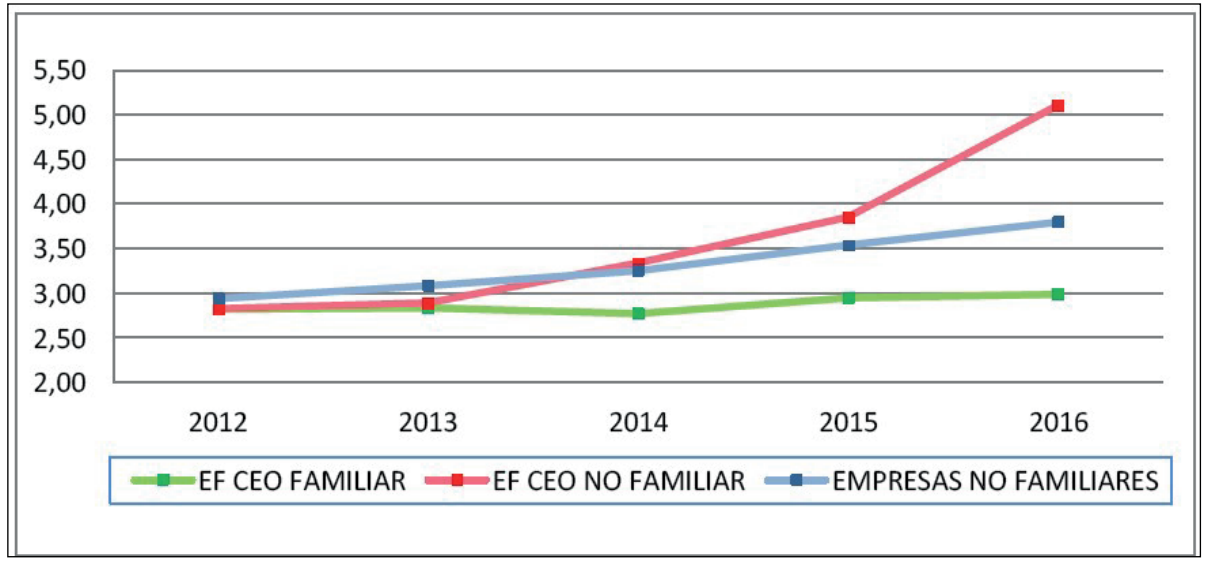

En el gràfic es pot observar que aquest ràtio s'ha mantingut constant durant el període analitzat per a l'empresa familiar que el seu CEO pertany la família, mentre que en el cas de les empreses amb CEO extern i les empreses no familiars es pot observar una tendència ascendent. Aquest ràtio ha anat augmentat durant el període analitzat arribant a aconseguir valors de 3,80 i 5,11 respectivament, l'any 2016.

Un dels motius pels quals les empreses familiars amb CEO familiar presenten menor garantia respecte als altres dos grups d'empreses, podria ser el fet que aquest tipus d'empreses davant la necessitat de finançament prefereixen optar primer per l'endeutament bancari que per l'ampliació de capital, atès que l'ampliació de capital implicaria pèrdua de control de l'empresa (Corona, 2005).

Un altre dels motius, podria ser el fet que les empreses familiars generalment obtenen millors condicions per part dels creditors ja que aquests perceben major protecció dels seus interessos gràcies a la vinculació dels propietaris amb l'empresa (Corona, 2005).

Per tant, en quant a garantía, s'observa un comportament semblant entre les empreses familiars amb CEO extern i les empreses no familiars. 


\subsubsection{Ràtio de Cobertura}

Ràtio de cobertura $=($ Patrimoni Net + Passiu no corrent $) /$ Actiu no corrent

Taula 7. Ràtio de cobertura

\begin{tabular}{|lccccc|}
\hline Tipus d'empresa & $\mathbf{2 0 1 2}$ & $\mathbf{2 0 1 3}$ & $\mathbf{2 0 1 4}$ & $\mathbf{2 0 1 5}$ & $\mathbf{2 0 1 6}$ \\
\hline Empresa familiar CEO familiar & 3,08 & 3,23 & 3,38 & 3,06 & 3,38 \\
Empresa familiar CEO extern & 3,35 & 3,47 & 3,15 & 2,99 & 3,20 \\
Empresa no familiar & 4,11 & 4,38 & 3,96 & 4,59 & 4,92 \\
\hline
\end{tabular}

El ràtio de cobertura indica la capacitat dels recursos permanents, és a dir, els recursos propis més els aliens de l'empresa, per a finançar l'actiu no corrent o immobilitzat. És aconsellable que el valor d'aquest ràtio superi la unitat, és a dir que els recursos permanents cobreixin el total de les inversions no corrents i encara quedin recursos excedents per a cobrir una part de l'actiu corrent.

Com es pot observar en la taula els resultats no sols superen la unitat sinó que estan molt per damunt per als tres grups d'empreses analitzats, la qual cosa significa que les inversions no corrents estan cobertes íntegrament i encara queda excedent per a cobrir una part de l'actiu corrent.

Figura 3. Evolució ràtio de cobertura empreses no familiars i empreses familiars amb CEO familiar i extern durant el període 2012-2016

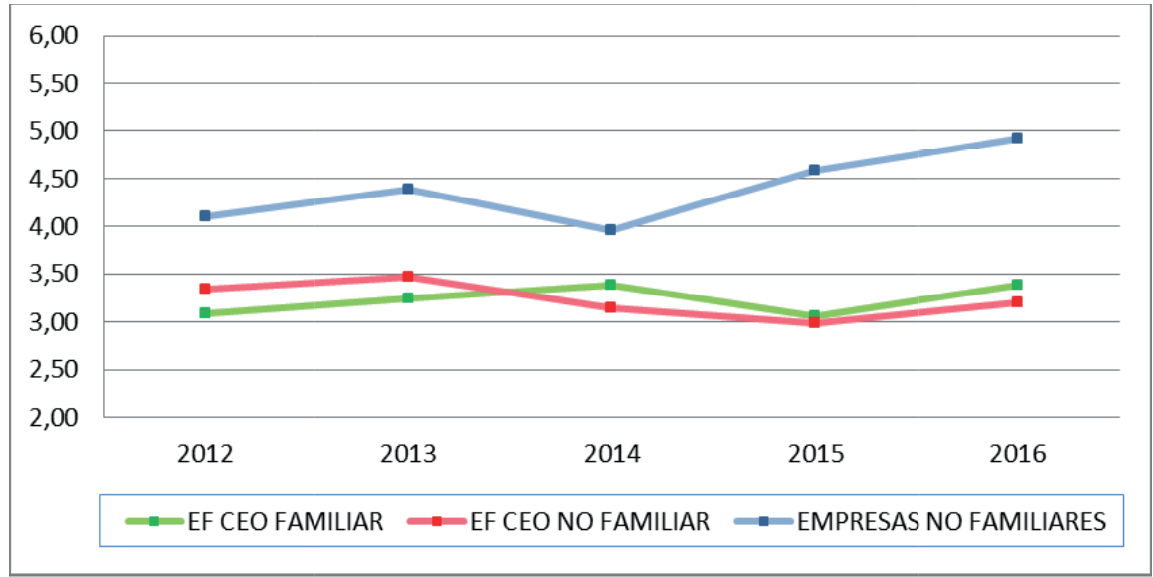

Si s'observa la seva evolució, d'una banda veiem que durant el període d'anàlisi les empreses familiars, independentment que el CEO sigui de la família o no, no presenten fluctuacions significatives i que el valor del ràtio de cobertura es troba entre 3 i 3,5 en tots dos casos.

D'altra banda, pel que fa a la mostra d'empreses no familiars, es pot observar una tendència creixent, ja que el valor del ràtio de cobertura s'ha vist incrementat durant 
aquest període. També es pot observar que el valor d'aquest ràtio se situa per sobre de 4 pràcticament en tots els anys analitzats.

Finalment, es pot afirmar que les empreses financen amb recursos estables tant l'actiu fix com part de l'actiu corrent.

\subsubsection{Ràtio de liquiditat o Fons de Maniobra}

Ràtio de Liquiditat $=$ Actiu corrent $/$ Passiu corrent

Taula 8. Ràtio de liquiditat.

\begin{tabular}{|lccccc|}
\hline Tipus d'empresa & $\mathbf{2 0 1 2}$ & $\mathbf{2 0 1 3}$ & $\mathbf{2 0 1 4}$ & $\mathbf{2 0 1 5}$ & $\mathbf{2 0 1 6}$ \\
\hline Empresa familiar CEO familiar & 2,71 & 2,98 & 2,86 & 3,04 & 3,03 \\
Empresa familiar CEO extern & 2,07 & 2,10 & 2,45 & 2,38 & 3,19 \\
Empresa no familiar & 2,29 & 2,54 & 2,64 & 2,72 & 3,13 \\
\hline
\end{tabular}

El ràtio de liquiditat mostra la capacitat que té l'empresa per a afrontar el pagament de les seves obligacions més immediates. Ens indica quants euros té l'empresa en béns i drets de l'actiu corrent per cada euro que té de deute a curt termini.

Per a poder garantir la seguretat de pagament dels deutes a curt termini amb l'actiu corrent el valor d'aquest ràtio ha de ser superior a 1 . Si el resultat és inferior, l'empresa no compta amb solvència adequada per a fer front al seu deute a curt termini. En cas contrari, si el valor del ràtio de liquiditat se situa per sobre de 1 , significa que l'empresa compta amb un fons de maniobra positiu, és a dir, que l'empresa disposa de circulant suficient per a liquidar els deutes a curt termini .

En la taula anterior es pot veure que els resultats del ràtio de liquiditat són superiors a 2 per als tres tipus d'empreses durant tot el període d'anàlisi, i que fins i tot arriba a superar les 3 unitats en l'últim any, per tant, el fons de maniobra és positiu i els tres grups d'empreses poden atendre les seves obligacions més immediates sense dificultats ja que no presenten problemes de liquiditat.

En quant a l'evolució, es pot apreciar que el ràtio de liquiditat ha fluctuat al llarg del període examinat i que té una tendència creixent en els tres casos.

El ràtio de liquiditat mostra valors semblants entre els tres tipus d'empreses, així i tot, cal destacar, que en el cas de les empreses amb un $\mathrm{CEO}$ familiar, aquest ràtio presenta valors superiors respecte a les empreses no familiars i les empreses familiars amb CEO extern, en pràcticament tots els anys analitzats. Per tant, això posa de manifest que, en general, les empreses familiars amb un CEO familiar mantenen majors nivells de liquiditat a causa de l'aversió al risc dels seus directius. 
Figura 4. Evolució ràtio de liquiditat empreses no familiars i empreses familiars amb CEO familiar i extern durant el període 2012-2016

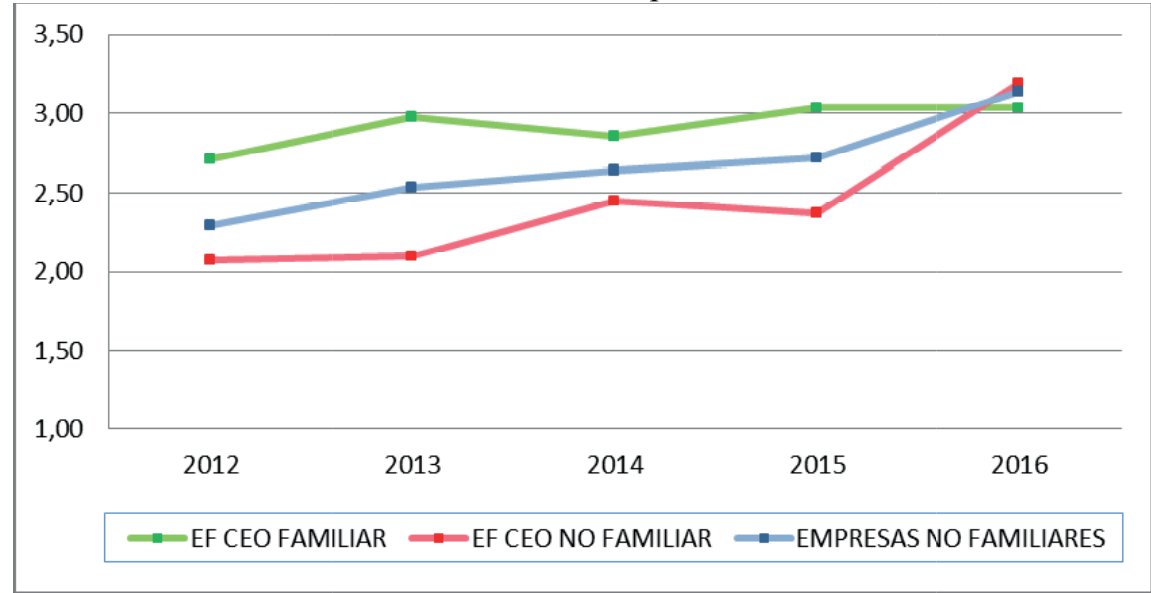

En quant a les empreses familiars amb CEO extern, s'observa que aquestes s'assemblen més a les empreses no familiars, ja que opten per mantenir nivells de liquiditat més baixos.

\subsubsection{Ràtio d'endeutament}

Ràtio d'endeutament $=$ Passiu exigible / Patrimoni Net

El ràtio d'endeutament és el quocient que relaciona el passiu exigible de l'empresa amb els recursos propis d'aquesta, és a dir, els deutes tant a llarg com a curt termini, amb el seu patrimoni net. Ens indica el finançament aliè amb el qual compta l'empresa, de manera que un major resultat implica un major nivell d'endeutament per part de l'empresa. En la següent taula es mostren els valors obtinguts:

\section{Taula 9. Ràtio d'endeutament}

\begin{tabular}{|lccccc|}
\hline Tipus d'empresa & $\mathbf{2 0 1 2}$ & $\mathbf{2 0 1 3}$ & $\mathbf{2 0 1 4}$ & $\mathbf{2 0 1 5}$ & $\mathbf{2 0 1 6}$ \\
\hline Empresa familiar CEO familiar & 3,61 & 3,32 & 3,39 & 2,94 & 2,53 \\
Empresa familiar CEO extern & 3,02 & 3,50 & 3,30 & 5,25 & 2,68 \\
Empresa no familiar & 3,87 & 4,19 & 3,93 & 3,40 & 3,21 \\
\hline
\end{tabular}

Segons els valors obtinguts en la taula podem veure que el ràtio d'endeutament presenta valors molt elevats, superiors a 3 pràcticament en tots els anys analitzats, la qual cosa significa que una part important dels recursos financers dels quals disposen les empreses provenen de deutes financers. Aquest fet ens indica un nivell excessiu d'endeutament per part de les empreses. 
Figura 5. Evolució ràtio d'endeutament empreses no familiars i empreses familiars amb CEO familiar i extern durant el període 2012-2016

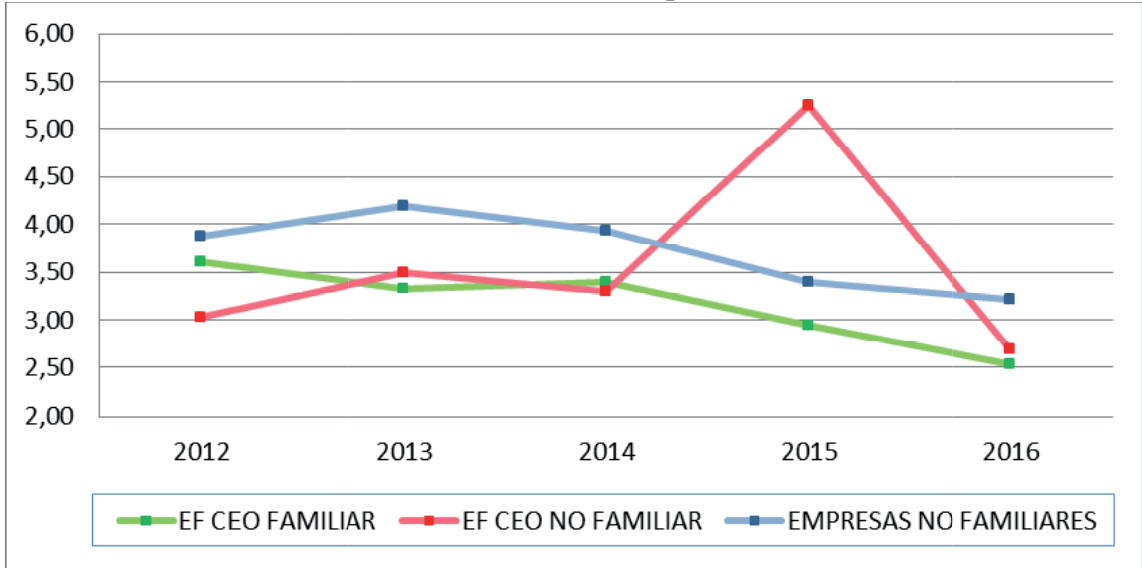

En el cas de les empreses familiars amb CEO membre de la família, s'observa que el ràtio indica resultats més baixos respecte els altres dos grups d'empreses, i que a més, aquest grup d'empreses va reduir la seva dependència de recursos aliens significativament, no obstant això es continua considerant un volum de deute excessiu.

Respecte a la mostra d'empreses no familiars es pot dir que aquestes compten amb un ràtio molt elevat, que fins i tot arriba a superar les quatre unitats l'any 2013, la qual cosa indica que estan molt endeutades. També cal assenyalar que durant aquest període el nivell d'endeutament ha anat disminuint, situant-se en 3,21 l'any 2016.

Si comparem els tres grups d'empreses, podem observar, que tant les empreses no familiars com les empreses familiars amb CEO extern, presenten valors superiors en termes mitjans respecte a les empreses familiars amb CEO familiar, i per tant, major endeutament $\mathrm{i}$ un nivell de risc financer major.

Aquests resultats posen de manifest la voluntat dels directius familiars per finançar l'empresa amb els seus propis recursos.

Respecte a les empreses no familiars i les familiars amb CEO extern, els resultats obtinguts corroboren una vegada més l'existència d'un comportament semblant entre aquests dos tipus d'empreses, pel fet que mostren una major preferència per l'endeutament. 


\subsubsection{Ràtio endeutament amb cost}

Ràtio d'endeutament amb cost $=$ Recursos aliens amb cost $/$ Patrimoni Net

Taula 10. Ràtio d'endeutament amb cost

\begin{tabular}{|lccccc|}
\hline Tipus d'empresa & $\mathbf{2 0 1 2}$ & $\mathbf{2 0 1 3}$ & $\mathbf{2 0 1 4}$ & $\mathbf{2 0 1 5}$ & $\mathbf{2 0 1 6}$ \\
\hline Empresa familiar CEO familiar & 2,20 & 2,06 & 2,08 & 1,86 & 1,53 \\
Empresa familiar CEO extern & 1,40 & 1,72 & 1,44 & 1,93 & 1,47 \\
Empresa no familiar & 1,51 & 1,93 & 1,67 & 1,60 & 1,60 \\
\hline
\end{tabular}

Aquest ràtio, relaciona la proporció de recursos aliens amb cost amb el patrimoni net o recursos propis. Per tant, ens permet conèixer quina proporció de deute representa un cost financer per a l'empresa.

Segons els resultats que es mostren en la taula no existeixen diferències significatives entre els tres tipus d'empreses, així i tot, cal assenyalar que tant en el cas que el CEO no sigui membre de la família com en el cas de les empreses no familiars, aquest ràtio indica valors lleugerament inferiors respecte a la mostra d'empreses familiars en què el seu CEO pertany a la família.

Tal com s'ha esmentat en apartats anteriors, l'empresa familiar, malgrat tenir major aversió al risc, davant la necessitat de finançament optarà per acudir a l'endeutament bancari per a evitar l'entrada de nous socis en l'empresa. Això explicaria el major endeutament amb cost per part de les empreses familiars amb CEO familiar.

\subsubsection{Qualitat del deute}

Qualitat del deute $=$ Passiu Corrent $/$ Passiu Total

Taula 11. Qualitat del deute

\begin{tabular}{|lccccc|}
\hline Tipus d'empresa & $\mathbf{2 0 1 2}$ & $\mathbf{2 0 1 3}$ & $\mathbf{2 0 1 4}$ & $\mathbf{2 0 1 5}$ & $\mathbf{2 0 1 6}$ \\
\hline Empresa familiar CEO familiar & $67,82 \%$ & $67,86 \%$ & $67,95 \%$ & $68,02 \%$ & $69,35 \%$ \\
Empresa familiar CEO extern & $70,37 \%$ & $68,52 \%$ & $68,95 \%$ & $67,58 \%$ & $69,03 \%$ \\
Empresa no familiar & $73,13 \%$ & $72,82 \%$ & $73,66 \%$ & $73,59 \%$ & $73,98 \%$ \\
\hline
\end{tabular}

Aquest quocient relaciona el passiu corrent, és a dir els deutes que té l'empresa a curt termini, amb el passiu total, i determina la proporció que representa el deute a curt termini sobre el total del deute. Per tant, com més baix sigui el resultat significa que major serà la facilitat per a retornar els fons aliens i millor serà la qualitat del deute en el que a termini es refereix.

Si s'observa la taula anterior, es pot veure que les diferències que presenten els tres grups d'empreses són mínimes, ja que els resultats obtinguts són molt semblants en 
quant a la qualitat del deute. Respecte a l'evolució del ràtio, aquest s'ha mantingut constant durant el període analitzat, ja que no presenta variacions significatives.

No obstant això, si comprem la proporció de deutes que són exigibles a curt termini amb els nivells de liquiditat de cada tipus d'empresa, si podem identificar certes diferències. Anteriorment, s'ha pogut comprovar que en el cas que el CEO sigui membre de la família, les empreses disposen d'un nivell liquiditat major respecte als altres dos grups d'empreses, és a dir, encara que el seu nivell de deute exigible a curt termini és molt semblant, l'actiu corrent del qual disposen és superior. Per tant, es dedueix que aquest tipus d'empreses familiars estaran més ben preparades per a complir amb els seus compromisos de pagament a curt termini.

\subsubsection{Cost de l'endeutament}

Cost endeutament $=$ Despeses financeres $/$ Recursos aliens amb cost

El cost d'endeutament fa referència al cost que ha de suportar una empresa per a poder desenvolupar la seva activitat a través dels recursos aliens, i es mesura com el quocient ens les despeses financeres i els recursos aliens amb cost.

Tal i com es pot observar en la taula, el cost d'endeutament que suporten els tres grups d'empreses durant el període d'anàlisi oscil la entre el $4.5 \%$ i el 6.5\%, aproximadament.

Taula 12. Cost d'endeutament

\begin{tabular}{|lccccc|}
\hline Tipus d'empresa & $\mathbf{2 0 1 2}$ & $\mathbf{2 0 1 3}$ & $\mathbf{2 0 1 4}$ & $\mathbf{2 0 1 5}$ & $\mathbf{2 0 1 6}$ \\
\hline Empresa familiar CEO familiar & $6,18 \%$ & $5,88 \%$ & $5,48 \%$ & $4,96 \%$ & $4,61 \%$ \\
Empresa familiar CEO extern & $6,41 \%$ & $6,49 \%$ & $5,69 \%$ & $4,65 \%$ & $4,49 \%$ \\
Empresa no familiar & $6,52 \%$ & $6,22 \%$ & $6,04 \%$ & $5,41 \%$ & $5,14 \%$ \\
\hline
\end{tabular}

Del següent gràfic es dedueix que al inici del període, l'any 2012, no existia una diferència important entre els tres grups d'empreses i que el cost aplicat per les entitats financeres en termes mitjans se situava al voltant del $6.5 \%$. A partir del següent exercici, any 2013, es pot notar com els valors d'aquest ràtio van disminuint i aquesta tendència es manté fins a finals del període, l'any 2016.

Analitzant el gràfic, també es pot observar que les empreses no familiars són les que suporten un major cost per part de les entitats bancàries, seguides de les empreses familiars amb CEO extern, a excepció de l'exercici 2015, any en què el cost que suporta aquest tipus d'empreses se situa per sota del valor obtingut per les empreses familiars amb CEO familiar.

Si bé les diferències que es presenten no són significatives, en conclusió, es podria dir que són les empreses familiars en què els seus CEOs formen part de la família les que obtenen millors condicions per part de les entitats financeres. Un resultat que es justificaria per la major confiança que les entitats financeres tenen en aquest tipus d'empreses. Aquesta confiança s'explica tant pel fet que els propietaris familiars són coneguts des de fa més anys, com sobretot pel fet que la supervivència és el principal 
objectiu d'aquestes, amb el que sobre el paper és més difícil que es generin impagaments per fallida.

Figura 6. Evolució cost de l'endeutament empreses no familiars i empreses familiars amb CEO familiar i extern durant el període 2012-2016

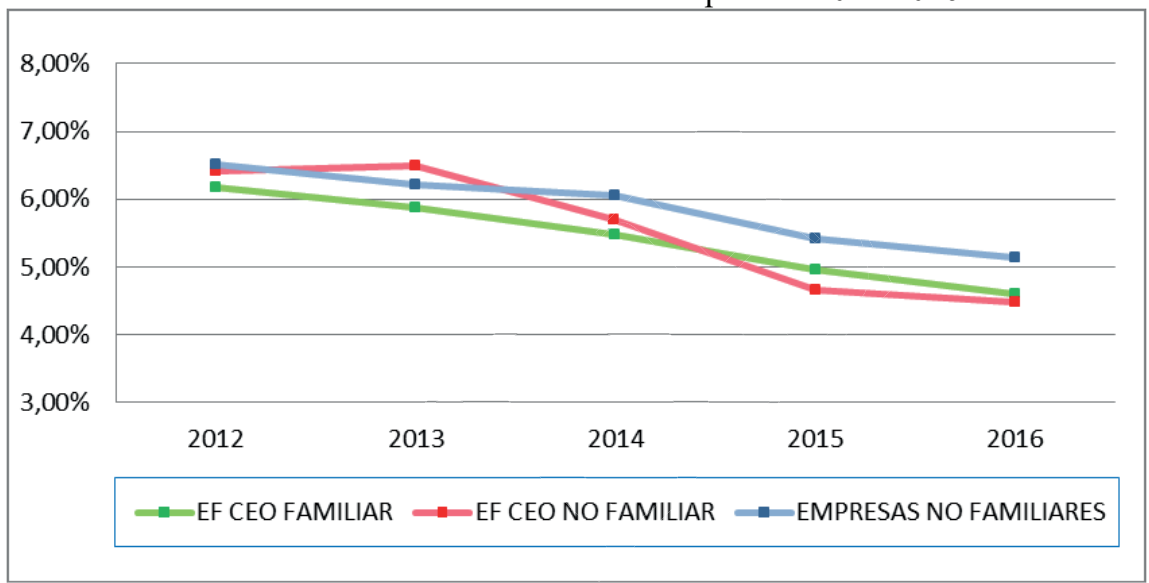

\subsection{Rendibilitat}

\subsubsection{ROA}

ROA = Benefici explotació / Total Actiu

La rendibilitat econòmica coneguda per les sigles ROA (Return on Assets) mesura el benefici que s'obté en relació amb les inversions de l'empresa mitjançant el desenvolupament de la seva activitat, és a dir, el rendiment que s'obté per cada euro invertit en actiu. En aquest cas, s'ha calculat com el quocient entre el benefici net i el total d'actiu de l'empresa, ja que és el ràtio de rendibilitat econòmica que proporciona la base de dades SABI.

Si els resultats del ràtio de rendibilitat són majors que el cost del deute, aleshores l'empresa el pot suportar, en cas contrari, si és inferior o pròxim a zero, l'empresa no té futur a llarg termini, ja que no obté rendiments dels seus actius.

Taula 13. Rendibilitat econòmica (ROA)

\begin{tabular}{|lccccc|}
\hline Tipus d'empresa & $\mathbf{2 0 1 2}$ & $\mathbf{2 0 1 3}$ & $\mathbf{2 0 1 4}$ & $\mathbf{2 0 1 5}$ & $\mathbf{2 0 1 6}$ \\
\hline Empresa familiar CEO familiar & $2,15 \%$ & $2,46 \%$ & $3,09 \%$ & $4,62 \%$ & $4,06 \%$ \\
Empresa familiar CEO extern & $2,85 \%$ & $3,81 \%$ & $3,14 \%$ & $4,89 \%$ & $1,78 \%$ \\
Empresa no familiar & $1,47 \%$ & $2,38 \%$ & $3,52 \%$ & $5,38 \%$ & $5,90 \%$ \\
\hline
\end{tabular}

La taula anterior posa de manifest que les empreses familiars amb un CEO extern gaudeixen de majors rendibilitats respecte a les empreses familiars amb CEO familiar durant gairebé tot el període analitzat, excepte l'any 2016 quan obtenen una rendibilitat inferior que se situa en el 1,78\%. 
Si ens fixem en els valors del ràtio de rendibilitat econòmica de les empreses no familiars podem veure que té una evolució positiva al llarg del període estudiat. Els valors més baixos per a aquest tipus d'empresa s'obtenen els dos primers anys, i el més alt en l'exercici 2016.

En quant a l'evolució del ràtio de rendibilitat econòmica dels tres grups d'empreses observem que en general la seva tendència és ascendent.

Per tant, tal com s'ha comentat en l'apartat 3.2 d'aquest mateix treball, una major rendibilitat per part de les empreses familiars amb CEO extern es podria justificar per la major orientació a beneficis que presenten aquest tipus de directius, la qual cosa mostra de nou un comportament més semblant al d'una empresa no familiar.

\subsubsection{Efecte palanquejament}

Efecte palanquejament $=\mathrm{ROA}-$ Cost de l'endeutament (i)

L'efecte palanquejament relaciona la rendibilitat de l'empresa amb el cost dels recursos aliens. De manera que tenim tres possibilitats:

- (ROA - i) > 0: palanquejament positiu. Indica que l'empresa disposa d'oportunitats d'inversió capaces de proporcionar unes rendibilitats superiors al cost d'utilització del deute i, per tant, serà beneficiós per als accionistes que l'empresa s'endeuti ja que permetrà una millora de la rendibilitat dels fons propis.

- $($ ROA - i) = 0: palanquejament neutre. L'ús de capital aliè no afecta la rendibilitat, és a dir, per a l'empresa és indiferent finançar-se amb deute o amb recursos propis.

- (ROA - i ) < 0: palanquejament negatiu. Indica que la rendibilitat obtinguda de les inversions és inferior al cost del deute, el que significa que l'ús de capital aliè provoca una reducció de la rendibilitat dels recursos propis.

En conclusió, sempre que el cost d'utilització del deute sigui inferior a la rendibilitat de les inversions, l'endeutament serà beneficiós per a l'empresa.

En la següent taula es mostren els resultats obtinguts:

Taula 14. Efecte palanquejament

\begin{tabular}{|lccccc|}
\hline Tipus d'empresa & $\mathbf{2 0 1 2}$ & $\mathbf{2 0 1 3}$ & $\mathbf{2 0 1 4}$ & $\mathbf{2 0 1 5}$ & $\mathbf{2 0 1 6}$ \\
\hline Empresa familiar CEO familiar & $-4,03 \%$ & $-3,42 \%$ & $-2,39 \%$ & $-0,34 \%$ & $-0,55 \%$ \\
Empresa familiar CEO extern & $-3,56 \%$ & $-2,68 \%$ & $-2,55 \%$ & $0,24 \%$ & $-2,71 \%$ \\
Empresa no familiar & $-5,04 \%$ & $-3,85 \%$ & $-2,53 \%$ & $-0,04 \%$ & $0,76 \%$ \\
\hline
\end{tabular}

Els resultats mostren que els tres grups d'empreses, excepte les empreses no familiars en l'exercici 2016, presenten un palanquejament negatiu durant tot el període objecte d'anàlisi, la qual cosa indica que la rendibilitat obtinguda de les inversions és inferior al cost del capital aliè que han de suportar. Per tant, l'endeutament no resulta beneficiós per a les empreses. 


\section{Conclusions}

Des d'un punt de vista teòric $\mathrm{i}$ segons els estudis realitzats per diversos autors ja citats anteriorment en aquest treball, s'ha pogut observar que la procedència del CEO que dirigeix l'empresa familiar, és a dir, si és membre de la família o extern, influeix en la forma de gestió d'aquesta. Aquests dos tipus d'empreses, empreses familiars amb CEO familiar i CEO extern, han mostrat diferències en quant a polítiques d'endeutament, dimensió, creixement, i polítiques de distribució de beneficis.

L'objectiu principal d'aquest treball ha estat determinar si realment aquest estil de gestió dels CEO externs en les empreses familiars s'aproxima més a un estil característic dels directius de les empreses no familiars. Per aquest motiu, s'ha dut a terme un estudi empíric basat en les mostres dels tres tipus d'empreses durant el període 2012-2016, amb l'ajuda del qual, s'ha pogut comprovar que l'estil de gestió dels CEO externs s'assembla al d'una empresa no familiar. Aquests dos tipus d'empreses presenten resultats similars pel que fa a:

a) Dimensió i creixement: majors creixements en termes mitjans en els seus nivells d'actius.

\section{b) Estructura financera:}

- Liquiditat: s'ha observat que mantenen nivells de liquiditat més baixos respecte a les empreses familiars amb CEO familiar, ja que tendeixen a assumir més riscos.

- Endeutament: davant la necessitat de finançament mostren una major preferència per l'endeutament bancari.

- Qualitat del deute: les empreses no familiars i les empreses familiars amb CEO extern estan pitjor preparades per a complir amb els seus compromisos de pagament a curt termini, pel fet que els seus nivells de liquiditat es mantenen baixos.

- Cost de l'endeutament: suporten major cost per part de les entitats financeres respecte a les empreses familiars amb CEO familiar. Això s'explica pel fet que l'objectiu principal dels propietaris familiars és la supervivència de l'empresa, el que genera major confiança en les entitats financeres.

c) Rendibilitat: les empreses amb CEO familiar obtenen menors rendibilitats, la qual cosa es justifica per la major orientació a beneficis dels directius de les empreses no familiars i els CEO externs de les empreses familiars.

\section{Referències:}

Agrawal, A. i Nagarajan, N.J. (1990). "Corporate Capital Structure, Agency Costs, and Ownership Control: The Casi of All-Equity Firms". The Journal of Finance, 4, 132531.

Amat, J.M. (2004). "La Continuidad de La Empresa Familiar". [Barcelona]: Gestión 2000

Barnes, L.B. i Hershon, S.A. (1994). "Transferring Power in the Family Business". Family Business Review, 53(4), 105-14. 
Burkart, M.; Gromb, D. i Panunzi, F. (1997). "Large Shareholders, Monitoring, and the Value of the Firm". The Quarterly Journal of Economics, 112, 693-728.

Burkart, M.; Panunzi, F. Shleifer, A. (2003). "Family Firms". Journal of Finance, 58, 2167-2202.

Castaldi, R.M. (1986). "An Analysis of the Work Rols of CEOs of Small Firms". American Journal of Small Business, 11(1), 53-64.

Comisión Europea. (2015). "Guía Del Usuario Sobre La Definición Del Concepto de Pyme". Oficina de Publicaciones de la Unión Europea.

Corona, J. (2005). Manual de La Empresa Familiar. Barcelona : Deusto.

Davis, PS i Harveston. P.D. (1998). "The Influence of Family on the Family Business Succession Process: A Multi-Generational Perspective”. Entrepreneurship Theory and Practice, 22(3), 31-53.

Devers, C.E., Cannella, A.A. Reilly, G.P. i Yoder, M.E . (2007). "Executive Compensation: A Multidisciplinary Review of Recent Developments". Journal of Management, 33(6), 1016-72.

Duréndez, A. i García, D. (2005). "Diferencias Económico-Financieras Entre Las Empresas Familiares y Las No Familiares". Revista de Contabilidad y Dirección, 2, 243-67.

Etebari, A., Horrigan, J.O. i Landwehr, J.L. (1987). "To Be Or Not to Be - Reaction of Estoc Returns to Sudden Deaths of Corporate Chief Executive Officers". Journal of Business Finance \& Accounting, 14(2), 255-78.

Filbeck, Greg, i Lee, S. (2000). "Financial Management Techniques in Family Businesses". Family Business Review, 13(3), 201-16.

Finkelstein, S. i Hambrick, C.D. (2009). "Strategic Leadership: Top Executive and Their Effects on Organizations". The Academy of Management Review, 22(3), 802-805.

Instituto de empresa familiar. (2018). "Factores de Competitividad y Analisis Financiero de La Empresa Familiar". Editado por IEF.

Instituto de la Empresa Familiar. (2015). “La Empresa Familiar En España”. Editado por IEF.

Jensen, M.C. i Meckling, W.H.. (1976). "Theory of the Firm: Managerial Behavior, Agency Costs and Ownership Structure". Journal of Financial Economics, 3, 305-60.

Jensen, M.C. i Murphy, K.J. (1990). "Performance Pay and Top-Management Incentivis”. Journal of Political Economy, 98(2), 225-64.

Lin, S.H. i Hu, S.I. (2007). "A Family Member or Professional Management? The Choice of a CEO and Its Impact on Performance". Corporate Governance: An International Review, 15(6), 1348-62.

Lyagoubi, M. (2006). "Family Firms and Financial Behavior: How Family Shareholder Preferences Influence Firms' Financing”. In Handbook of Research on Family Business. Ed. Poutziouris, P.Z.; Smyrnios, KX. I Klein, S.B.

Mahérault, L. (2000). "The Influence of Going Public on Investment Policy: An Empirical Study of French Family-Owned Businesses". Family Business Review, 13(1), 71-79. 
Mishra, C.S. i Mcconaughy, D.L. (1999). "Founding Family Control and Capital Structure: The Risk of Loss of Control and the Aversion to Debt". Entrepreneurship Theory and Practice, 23(4), 53-64.

Sánchez, L.; Gallizo, J.L. y Moreno, J. (2019). "Influencia del CEO en la empresa familiar cotizada". Intangible Capital, 15(2), 1-20.

Shanker, M.C. i Astrachan, J.H. (1996). "Myths and Realities: Family Businesses' Contribution to the US Economy- a Framework for Assessing Family Business Statistics". Family Business Review, 9(2), 107-123.

Ward, J.L. (1988). "The Special Role of Strategic Planning for Family Businesses”. Family Business Review, 1(2), 105-117. 